\title{
KORELASI ANTARA KESIAPAN BELAJAR DENGAN HASIL BELAJAR SISWA DI SMA NEGERI 5 LAHAT
}

\author{
Deni Puji Hartono \\ Pendidikan Geografi, FKIP, Universitas PGRI Palembang \\ denipujihartono03@gmail.com
}

\begin{tabular}{lrr}
\hline \multicolumn{3}{c}{ INFO ARTIKEL } \\
\hline \multicolumn{2}{l}{ Riwayat } & Artikel: \\
Dikirim & $:$ & $29-01-2021$ \\
Disetujui & $:$ & $30-01-2021$ \\
Diterbitkan & $:$ & $31-01-2021$
\end{tabular}

\section{Kata kunci:}

Geografi; Hasil Belajar;

Kesiapan Belajar

\begin{abstract}
ABSTRAK
Abstract: The aim of this study is to determine the correlation between the readiness to learn and result study of the students'on geography subjects in SMAN 5 Lahat. This research used descriptive quantitative method. The number of population is less than 100 people, in this study the sample is 63 students. The data collection techniques used documentation and questionnaires. The results of this study showed that the average score of student learning readiness of $79.66 \%$ on the criteria of being and the average student learning outcomes $82.86 \%$ on good criteria. Testing the hypothesis on the level of $95 \%$ or 0.05 indicates $\alpha r$ $x y=0.9133>0.05 \alpha$ rt $n=63=0.249$ and thitung $>$ ttable ie 34.12> 1.999 is means there is a positive relationship between learning readiness and students' learning readiness and learning outcomes is $91.33 \%$ with high criteria. So, it means there is a significant corection between the learning readiness and the students' learning outcomes at SMAN 5 Lahat.
\end{abstract}

\section{PENDAHULUAN}

Pendidikan adalah salah satu cara yang ditempuh oleh seseorang untuk memperoleh pengetahuan agar dapat ditransformasikan dalam kehidupan sehari-hari. Seorang pendidik di Sekolah Menengah Atas (SMA) hendaknya memiliki profesional atas profesi yang dijalankannya. Kesiapan dalam mengajar merupakan satu sifat profesional dari seorang pendidik. Seorang peserta didik haruslah mampu dan dapat mempersiapkan serta melaksanakan proses kegiatan belajar dengan baik agar ilmu yang diperoleh mendapatkan manfaat yang lebih baik dan mampu mengaplikasikannya dalam kehidupan seharihari.

Kesiapan belajar geografi berarti kondisi yang dipersiapkan oleh guru untuk memberikan pembelajaran kepada siswa melalui pemahaman guru mengenai materi yang akan dipelajari, serta kondisi fisik, psikis dan materiil yang terdapat pada diri siswa dalam rangka menerima pembelajaran. Sesuai 
dengan pendapat yang disampaikan oleh Hamalik, (2003:41) bahwa "kesiapan adalah keadaan kapasitas yang ada pada diri siswa dalam hubungan dengan tujuan pengajaran tertentu".

Pelajaran Geografi merupakan mata pelajaran yang masuk dalamkelompok peminatan ilmi-ilmu sosial. Untuk mengetahui sejauh mana tingkat kesiapan pembelajaran dan tingkat keterampilan yang telah dimiliki siswa dalam pelajaran geografi biasanya diukur dari tingkat pencapaian prestasi belajarnya (Bujuri, 2015). Kesiapan belajar ini mempunyai peran yang sangat penting dalam menentukan dan mengarahkan siswa untuk dapat mengikuti pelajaran baru. Kesiapan merupakan hal utama yang harus diperhatikan dalam kegiatan pembelajaran itu sendiri, tanpa kesiapan atau kesediaan untuk belajar maka proses pembelajaran tidak akan terjadi.

Kurangnya kesiapan belajar siswa, hal ini dapat dilihat dari kesiapan fisik, psikis dan materiil, sehingga tidak dapat bersaing dengan temannya untuk memperoleh nilai yang lebih baik dalam proses pembelajaran (Masrya, 2019). Menurut Sanjaya (2010) "kesiapan belajar disiapkan agar siswa dapat menerima informasi sebagai stimulus yang kita berikan, terlebih dahulu kita harus memposisikan mereka dalam keadaan siap baik secara fisik maupun psikis untuk menerima pelajaran. Jangan mulai materi pelajaran, manakala siswa belum siap untuk menerimanya".

"Hasil belajar adalah pola-pola perbuatan, nilai-nilai pengertian, sikap-sikap, apresiasi dan keterampilan" (Suprijono, 2010). Sedangkan Sudjana, (2010) "Hasil belajar adalah kemampuan-kemampuan yang dimiliki siswa setelah ia menerima pengalaman belajar". Hasil belajar merupakan hasil dari interaksi belajar mengajar yang dapat berupa pengetahuan dan keterampilan, perubahan tingkah laku ke arah yang lebih positif, serta penerapan nilai-nilai pengetahuan yang ditunjukkan dari nilai tes yang diberikan oleh guru (Yulikasari \& Pramusinto, 2016).

Adanya kesiapan belajar sangat dibutuhkan agar siswa dapat memiliki kesediaan untuk memberikan respon atau bereaksi terhadap mata pelajaran. Kesiapan belajar tersebut antara lain kesiapan psikis dan kesiapan materill (Hartono, 2016). Khususnya pada mata pelajaran geografi, kesiapan belajar sangat menentukan keberhasilan pembelajaran, karena dalam proses pembelajaran geografi terkadang dibutuhkan bahan-bahan tambahan untuk mendukung proses pembelajaran. Bahan tersebut berupa peta, pemahaman terhadap bola dunia serta batas-batas wilayah.Oleh karena itu, sangat penting bagi pendidik dan peserta didik untuk mempersiapkan diri dalam rangka pelaksanaan pembelajaran.

Dengan begitu sangat besar kemungkinan hasil belajar yang akan dicapai anak akan baik. Hal ini berarti sangat erat hubungannya antara kesiapan belajar dengan hasil belajar yang ingin dicapai anak (Fitriana, \& Tri Indrianti, 2013). Pengajaran dikatakan berhasil atau tidak secara umum dapat dilihat dari dua segi, yakni kriteria ditinjau dari sudut proses pengajaran itu sendiri dan kriteria yang ditinjau dari sudut hasil atau produk belajar yang dicapai siswa (Wahyuni, 2005). Belajar tanpa kesiapan fisik, mental dan perlengkapan akan banyak mengalami kesulitan, akibatnya tidak memperoleh hasil belajar yang baik (Dalyono, 2009:52).

Berdasarkan pengamatan awal peneliti pada tanggal 17 Februari 2020, di SMA Negeri 5 Lahat bahwa kesiapan siswa dalam menerima pelajaran masih variatif yaitu masih terdapat siswa yang terlambat datang ke sekolah, lupa membawa buku atau tugas mata pelajaran yang akan dipelajari pada hari itu, serta kelengkapan tulis lainnya yang terkadang tidak tersedia. Hal ini berpengaruh terhadap proses pembelajaran yang implikasinya adalahhasil belajar siswa yang diperoleh tidak optimal.Berdasarkan informasi yang diperoleh dari guru mata pelajaran geografi diketahui bahwabelum semua siswa memperoleh nilai di atas Kriteria Ketuntasan Minimum (KKM), KKM yang diterapkan di SMA Negeri 5 Lahat adalah 75. Berdasarkan permasalahan yang telah diuraikan, maka penelitian ini bertujuan untuk mengetahui korelasi antara kesiapan belajar dengan hasil belajar siswa pada mata pelajaran geografi di SMA Negeri 5 Lahat

\section{METODE PENELITIAN}

Metode yang digunakan dalam penelitian ini adalah metode deskriptif kuantitatif. Teknik pengumpulan data menggunakan cara dokumentasi dan angket. 
Populasi dari penelitian ini adalah seluruh siswa kelas XI IPS SMA Negeri 5 Lahat yang belajar mata pelajaran geografi berjumlah 63 siswa yang terdiri dari 3 kelas. Sehubungan dengan jumlah populasi yang kurang dari 100 orang, maka penelitian ini menggunakan sampel populasi atau jumlah populasi dijadikan sebagai sampel penelitian.

Teknik analisis data dilakukan dengan bantuan software SPSS 16.0 for window dengan langkah pengujian persyaratan analisis dengan uji normalitas dengan menggunakan metode Chi Kuadrad, sedangkan untuk uji homogenitas dengan dilakukan dengan uji levene test, dan untuk pengujian hipotesis dilakukan dengan statistik parametrik yaitu korelasi produk momen.

\section{HASIL DAN PEMBAHASAN \\ Data Hasil Belajar}

Adapun hasil belajar siswa yang diperoleh dari guru menunjukkan data bahwa hanya terdapat 2 orang siswa atau dengan persentase $3,17 \%$ yang termasuk pada kategori cukup baik, pada kategori baik merupakan kategori yang dominan yaitu sebanyak 50 orang siswa atau dengan persentase $79,37 \%$, sedangkan pada kategori sangat baik terdapat 11 orang siswa atau sebesar $17,46 \%$.

Data hasil belajar yang diperoleh membuktikan bahwa hasil belajar siswa di SMA Negeri 5 Lahat pada mata pelajaran geografi dengan materi lingkungan hidup sudah baik, dibuktikan dengan rata-rata nilai yang diperoleh siswa telah melampaui nilai kriteria ketuntasan minimum yaitu sebesar 75 sedangkan rata-rata yang diperoleh siswa adalah 82,86. Hasil belajar siswa diperoleh dari dokumentasi yaitu nilai ulangan harian siswa pada materi lingkungan hidup yang diperoleh dari guru pada mata pelajaran geografi.Analisa data hasil belajar menggunakan persentasi yang terlihat seperti tabel 1 berikut ini:
Tabel 1. Distribusi Hasil Belajar Siswa Berdasarkan Persentase

\begin{tabular}{ccccc}
\hline No & Interval & Katagori & $\begin{array}{c}\text { Frek- } \\
\text { uensi }\end{array}$ & $\%$ \\
\hline 1 & $86-100$ & Sangat Baik & 11 & $17,46 \%$ \\
2 & $71-85$ & Baik & 50 & $79,37 \%$ \\
3 & $56-70$ & Cukup & 2 & $3,17 \%$ \\
4 & $41-55$ & Kurang & - & - \\
5 & $\leq 40$ & Sangat & - & - \\
& & Kurang & & \\
\hline $\begin{array}{c}\sum \\
\text { Rata- } \\
\text { rata }\end{array}$ & 82,86 & Baik & 63 & $100 \%$ \\
\hline & & & & - \\
\hline
\end{tabular}

Dari tabel 1 di atas diketahui bahwa persentase siswa yang memperoleh hasil belajar siswa pada kategori sangat kurang, kurang tidak terdapat satupun siswa, kategori cukup baik terdapat 2 orang siswa atau dengan persentase $3,17 \%$, pada kategori baik merupakan kategori yang dominan yaitu sebanyak 50 orang siswa atau dengan persentase $79,37 \%$, sedangkan pada kategori sangat baik terdapat 11 orang siswa atau sebesar $17,46 \%$. Jadi dapat disimpulkan bahwa nilai hasil belajar siswa mencapai harapan sekolah/guru kelas, yaitu melampaui nilai KKM sebesar 75,00 sedangkan nilai rata-rata yang diperoleh siswa yaitu sebesar 82,86 yang termasuk dalam kategori baik.

\section{Data Kesiapan Belajar}

Analisa data kesiapan belajar dengan menggunakan persentase yang hasilnya seperti terlihat pada tabel 2 berikut ini:

Tabel 2. Distribusi Kesiapan Belajar Siswa Berdasarkan Persentase

\begin{tabular}{|c|c|c|c|c|}
\hline Angket & $\begin{array}{c}\text { Nilai } \\
\text { berdasarkan } \\
\% \\
\end{array}$ & $\begin{array}{c}\text { Freku- } \\
\text { ensi }\end{array}$ & $\%$ & Kategori \\
\hline$X \leq 30$ & $X<40,0$ & - & - & $\begin{array}{c}\text { Sangat } \\
\text { Tidak Siap }\end{array}$ \\
\hline $\begin{array}{c}30<\mathrm{x} \leq \\
40\end{array}$ & $\begin{array}{c}40,0<\mathrm{x} \leq \\
54,04\end{array}$ & - & - & Tidak Siap \\
\hline $\begin{array}{c}40<\mathrm{x} \leq \\
50\end{array}$ & $\begin{array}{c}54,04<\mathrm{x} \leq \\
66,67\end{array}$ & 4 & $6,35 \%$ & $\begin{array}{c}\text { Cukup } \\
\text { Siap }\end{array}$ \\
\hline $\begin{array}{c}50<\mathrm{x} \leq \\
60\end{array}$ & $\begin{array}{c}66,67<\mathrm{x} \leq \\
80,00\end{array}$ & 32 & $\begin{array}{c}50,79 \\
\%\end{array}$ & Siap \\
\hline $\begin{array}{c}60<\mathrm{x} \leq \\
75\end{array}$ & $\begin{array}{c}80,00<\mathrm{x} \leq \\
100\end{array}$ & 27 & $\begin{array}{c}42,86 \\
\% \\
\end{array}$ & $\begin{array}{l}\text { Sangat } \\
\text { Siap }\end{array}$ \\
\hline \multicolumn{2}{|c|}{ Jumlah } & 63 & $100 \%$ & \\
\hline
\end{tabular}


Tabel 2 di atas menunjukan bahwa kesiapan belajar siswa pada kriteria sangat tidak siap, tidak siap tidak terdapat satupun siswa. Sedangkan kesiapan belajar pada kreteria cukup siap sebanyak 4 orang dengan persentase $6,35 \%$, kategori siap dan sangat siap memiliki 50,79\% dan 42,86\%. Dapat disimpulkan bahwa sebagian besar siswa memiliki kesiapan belajar yang siap.

\section{Pembahasan}

Berdasarkan pendapat Dimyati dan Mudjiono, (2009) "Hasil belajar adalah hasil dari suatu interaksi tidak belajar dan tidak mengajar dan biasanya ditunjukkan dengan nilai tes yang diberikan guru".Dari beberapa pendapat ahli di atas, dapat disimpulkan bahwa hasil belajar merupakan hasil dari interaksi belajar mengajar yang dapat berupa pengetahuan dan keterampilan yang ditunjukkan melalui tes yang di berikan oleh guru. Banyak faktorfaktor yang mempengaruhi hasil belajar, yaitu faktor intern antara lain kesehatan dan cacat tubuh, intelegensi, perhatian, minat, bakat, dan kesiapan sedangkan faktor ekstern antara lain lingkungan hidup, kondisi fisik dan iklim emosi.

Kesiapan belajar mempengaruhi perolehan hasil belajar siswa, setiap orang yang hendak melakukan kegiatan belajar harus memiliki kesiapan yakni dengan kemampuan yang cukup baik fisik, psikis, maupun materiil.Kesiapan fisik berarti memiliki tenaga cukup dan kesehatan yang baik.Kesiapan psikis, memiliki minat dan motivasi yang cukup untuk melakukan kegiatan belajar.Kesiapan materiil antara lain mempelajari materi yang akan dipelajari, melengkapi buku catatan, dan alat tulis untuk belajar disiapkan dengan baik.

Belajar tanpa kesiapan fisik, psikis dan materilakan banyak mengalami kesulitan, akibatnya tidak memperoleh hasil belajar yang baik. Seperti yang di sampaikan oleh Slameto, (2010) "Kesiapan adalah keseluruhan kondisi seseorang yang membuatnya siap untuk memberinya respons atau jawaban terhadap suatu situasi”.

Sejalan dengan hasil yang diperoleh dari penelitian ini yaitu sebagian besar siswa memiliki tingkat kesiapan belajar yang tinggi, sehingga proses pembelajaran geografi di SMA Negeri 5 Lahat dapat berjalan dengan baik. Oleh karena kesiapan belajar yang baik membuat hasil belajar yang diperoleh siswa pun baik, berdasarkan hasil ulangan harian siswa menunjukkan bahwa rata-rata nilai yang diperoleh siswa adalah 82,86 yang berarti baik.

Hasil penelitian ini sesuai dengan teori yang disampaikan oleh Slameto (2010), bahwa terdapat banyak faktor yang mempengaruhi hasil belajar diantaranya adalah kesiapan siswa untuk belajar.Penelitian ini telah membuktikan bahwa kesiapan belajar siswa menentukan tingkat keberhasilan siswa dalam belajar melalui indikator hasil ulangan harian siswa. Hasil penelitian ini diperkuat dengan pengujian hipotesis, dengan taraf kepercayaan diambil $95 \%$ atau $\alpha 0,05$ adalah $t_{\text {tabel }}$ pada siswa 63 orang adalah 0,249. Setelah dilakukan perhitungan dengan menggunakan rumus korelasi product moment untuk menguji signifikansi maka diperoleh hasil $\mathrm{r}_{\text {hitung }}=$ 0,9133 dan $r_{\text {tabel }}=0,249$ yang berarti $r_{\text {hitung }}>$ $\mathrm{r}_{\text {tabelatau }}$ 0,9133>0,249, Jadi Ha diterima dan Ho ditolak, artinya terdapat hubungan yang signifikan antara kesiapan belajar dengan hasil belajar dalam mata pelajaran Geografi di SMA Negeri 5 Lahat.

Hasil penelitian ini juga mendukung penelitian yang pernah dilakukan oleh Astuti, Zulkarnain, dan Widodo, (2013). Berdasarkan analisis data hasil penelitian menunjukkan bahwa: (1) Ada hubungan yang positif dan signifikan antara minat belajar dengan belajar prestasi belajar geografi di SMA Muhammadiyah 2 Bandar Lampung; (2) Ada hubungan yang positif dan signifikan antara kesiapan fisik dengan prestasi belajar Geografi kelas X SMA Muhammadiyah 2 Bandar Lampung tahun 2012-2013; (3) Ada hubungan yang positif dan signifikan antara kesiapan mental dengan prestasi belajar Geografi; (4) Ada hubungan yang positif dan signifikan antara kesiapan media dengan prestasi belajar Geografi di SMA Muhammadiyah 2 Bandar Lampung tahun 2012-2013.

Penelitian yang sejenis pernah dilakukan oleh Norita, Sumadi, Zulkarnain (2012), bahwa kesiapan belajar siswa memiliki hubungan positif dan signifikan antara kesiapan belajar dengan prestasi belajar Geografi siswa kelas X SMA Negeri 1 Kotabumi Lampung Utara Tahun Pelajaran 2011-2012. Dengan sampel penelitian yang 
berbeda memiliki hasil yang sama bahwa terdapat hubungan yang positif, sehingga penelitian ini menjadi pendukung penelitian yang telah dilakukan sebelumnya.

Penelitian yang dilakukan oleh Bujuri (2015) dengan hasil penelitian ada pengaruh yang signifikan motivasi belajar terhadap prestasi belajar geografi siswa kelas XI SMA Swadhipa Bumisari Natar tahun pelajaran 2014/2015 dengan kontribusi pengaruh sebesar 36,5 \%, (2) ada pengaruh yang signifikan kesiapan belajar terhadap prestasi belajar geografi siswa kelas XI SMA Swadhipa Bumisari Natar tahun pelajaran 2014/2015 dengan kontribusi pengaruh sebesar 33,2 \%, (3) ada pengaruh yang

\section{SIMPULAN}

Berdasarkan hasil analisis data yang telah diuraikan dapat ditarik kesimpulan bahwa dalam penelitian ini terdapat korelasi yang signifikan antara kesiapan belajar dengan hasil belajar siswa pada mata pelajaran Geografi di SMA Negeri 5 Lahat, dibuktikan dengan pengujian yang dilakukan $r_{\text {hitung }}>r_{\text {tabel; }}$ 0,9133> 0,249 . Besaran hubungan antara kesiapan belajar siswa dengan hasil belajar siswa sebesar $91,33 \%$ yaitu termasuk dalam kriteria hubungan yang sangat tinggi.

\section{REKOMENDASI}

Perlu adanya penelitian lanjutan untuk mengetahui hubungan kesiapan belajar tidak hanya sebatas hubungan dengan hasil belajar, namun bisa juga diteliti berdasarkan hubungan dalam meningkatkan motivasi, kreativitas, ataupun prestasi belajar.

\section{DAFTAR PUSTAKA}

Astuti, D. Y., Zulkarnain, \& Widodo, S. 2013. Hubungan Antara Minat Belajar dan Kesiapan Belajar dengan Prestasi Belajar Geografi. Jurnal Penelitian Geografi,Online:http://jurnal.fkip.unil a.ac.id/index.php/JPG/article/view/105 7 diakses pada tanggal 3 April 2020.

Bujuri, A. P. (2015). Pengaruh Motivasi Belajar Dan Kesiapan Belajar Terhadap Prestasi Belajar Geografi Siswa Kelas Xi Sma Swadhipa Bumisari Natar Tahun Pelajaran 2014/2015 (Doctoral signifikan motivasi belajar dan kesiapan belajar terhadap prestasi belajar geografi siswa kelas XI SMA Swadhipa Bumisari Natar tahun pelajaran 2014/2015, dengan kontribusi pengaruh sebesar $71,8 \%$.

Hal yang sama dengan pendapat yang disampaikan oleh Rusman (2012), yang menyatakan bahwa faktor internal diantaranya kesiapan belajar dapat mempengaruhi hasil belajar peserta didik. Oleh karena itu, hasil penelitian ini sesuai dengan teori-teori yang disampaikan oleh ahli dan mendukung penelitian sejenis yang telah dilakukan oleh peneliti-peneliti sebelumnya.

dissertation, Fakultas Keguruan dan Ilmu Pendidikan).

Dalyono. 2009. Psikologi Pendidikan. Jakarta: Rineka Cipta

Fitriana, E., \& Tri Indrianti, D. (2013). Hubungan antara Kesiapan Belajar Dengan Hasil Belajar Matematika Warga Belajar Kelas XI Kelompok Belajar Paket C SKB Bondowoso

Hamalik, D. O. 2010. Kurikulum dan Pembelajaran. Jakarta: PT. Bumi Aksara. 2003.

Hartono, D. P. (2016). Pengaruh Model Pembelajaran Student Team Achievement Division (STAD) Terhadap Hasil Belajar Mahasiswa Mata Kuliah Meteorologi Dan Klimatologi Universitas Pgri Palembang Tahun 2015. Jurnal Dosen Universitas PGRI Palembang.

Masrya, M. (2019). Kesiapan Belajar Siswa Kelas XI IPS Dalam Pembelajaran Geografi Di SMAN 12 Padang (Doctoral dissertation, STKIP PGRI Sumatera Barat).

Norita, W., Sumadi, \& Zulkarnain. 2012. Hubungan Antara Motivasi Belajar dan Kesiapan Belajar dengan Prestasi Belajar Geografi Siswa Kelas X SMA Negeri 1 Kotabumi Lampung Utara Tahun Pelajaran 2011-2012. FKIP UNILA, http://jurnal.fkip.unila.ac.id/index.php/ JPG/article/viewFile/661/381 diakses pada tanggal 27 Maret 2020 
Sanjaya, W. 2010. Strategi Pembelajaran Berorientasi Standar Proses Pendidikan. Jakarta: Kencana.

Slameto. 2010. Belajar dan Faktor-faktor yang Mempengaruhinya. Jakarta: PT. Rineka Cipta.

Sudjana, N. 2010. Penilaian Hasil Proses Belajar Mengajar. Bandung: PT. Remaja Rosdakarya.

Suprijono. 2010. Cooperative Learning. Yogyakarta: Pustaka Belajar.

Yulikasari, R., \& Pramusinto, H. (2016). Pengaruh Kesiapan Belajar, Kompetensi Profesional Guru Dan Lingkungan Belajar Terhadap Motivasi Belajar Mata Pelajaran Kearsipan. Economic Education Analysis Journal, 5(3), 825825.

Wahyuni, D. (2005). Pengaruh Kesiapan Belajar, Motivasi Belajar dan
Pengulangan Materi Pelajaran Terhadap Hasil Belajar Mata Pelajaran Ekonomi pada Siswa Kelas II MA Al Asror Gunung Pati Tahun Pelajaran 2004/2005. PhD diss., Universitas Negeri Semarang. 